\title{
NEW RECORDS OF CHRYSOPIDAE (NEUROPTERA) IN BRAZIL
}

\author{
Alberto Luiz Marsaro Júnior ${ }^{1}$, Sérgio de Freitas ${ }^{2}$, Ricardo Adaime ${ }^{3}$, Paulo Roberto Valle da Silva \\ Pereira $^{1}$ \\ ${ }^{1}$ Embrapa Trigo, Passo Fundo, Rio Grande do Sul, Brasil. \\ ${ }^{2}$ Universidade Estadual Paulista, Jaboticabal, São Paulo, Brasil. \\ ${ }^{3}$ Embrapa Amapá, Rodovia JK, km 5, n 2600, 68903-419, e-mail: adaime@ cpafap.embrapa.br, Macapá, Amapá, Brasil.
}

\begin{abstract}
This work reports certain species of Chrysopidae for the first time in the Brazilian state of Roraima, and in Brazil as well. The chrysopids were collected with McPhail traps in four municipalities of the state of Roraima, Amajari, Boa Vista, Bonfim and Pacaraima. All nine species of Leucochrysa identified in this work were reported for the first time in the state of Roraima, and L. (Nodita) amazonica (Navás) and L. (N.) pavida (Hagen) were reported for the first time in Brazil. Three species of Ceraeochrysa, namely $C$. acmon (Penny), C. caligata (Banks) and $C$. cincta (Schneider), were reported for the first time in Roraima; and C. valida (Banks) was reported for the first time in Brazil. Within the genus Plesiochrysa, P. brasiliensis (Schneider) was reported for the first time in Roraima. Species description is still required for the two new species identified in this work as Plesiochrysa sp. and Leucochrysa (N.) sp.
\end{abstract}

Key words: Amazon, Ceraeochrysa, Leucochrysa, Plesiochrysa, Roraima

\section{NOVOS REGISTROS DE CHRYSOPIDAE (NEUROPTERA) NO BRAZIL}

\section{RESUMO}

No presente trabalho foram feitos novos registros de espécies de Chrysopidae para o Estado de Roraima e para o Brasil. Os crisopídeos foram coletados com armadilhas tipo McPhail em quatro municípios de Roraima, Brasil: Amajari, Boa Vista, Bonfim e Pacaraima. Todas as nove espécies de Leucochrysa identificadas neste trabalho são reportadas pela primeira vez para o estado de Roraima, sendo que as espécies L. (Nodita) amazonica (Navás) e L. (N.) pavida (Hagen) foram registradas pela primeira vez no Brasil. Três espécies de Ceraeochrysa, C. acmon (Penny), C. caligata (Banks) e C. cincta (Schneider), foram registradas pela primeira vez em Roraima; e C. valida (Banks) foi registrada pela primeira vez no Brasil. No gênero Plesiochrysa, $P$. brasiliensis (Schneider) foi registrada pela primeira vez para Roraima. Duas novas espécies, denominadas neste trabalho Plesiochrysa sp. e Leucochrysa (N.) sp., ainda precisarão ser descritas.

Palavras-chave: Amazônia, Ceraeochrysa, Leucochrysa, Plesiochrysa, Roraima 


\section{INTRODUCTION}

Chrysopidae is the largest family of the Order Neuroptera, with approximately 1,200 species and subspecies distributed into 86 genera and subgenera grouped into the subfamilies Nothochrysinae, Chrysopinae and Apochrysinae. Chrysopinae stands out for its large number of species, which are grouped into four tribes: Ankylopterigini, Belonopterigini, Chrysopini, and Leucochrysini. Two of these tribes contain species that can potentially be used in biological control programs: Chrysopini (30 genera and 7 subgenera) and Leucochrysini (7 genera) (Brooks \& Barnard 1990).

Chrysopids are important agents for the biological control of pests, and surveys of these predators have already been completed in several states in most regions of Brazil: Northeast (Freitas 2005; Macedo \& Freitas 2008; Macedo \& Freitas 2011), Southeast (Galli et al. 2004; Souza et al. 2004; Freitas 2007; Montes et al. 2007a,b; Costa et al. 2010; Silva et al. 2011), South (Cardoso et al. 2003; Barbosa et al. 2009), and North (Adams \& Penny 1985; Maia et al. 2010).

The state of Roraima is located in the extreme north of the Brazilian Amazon, occupying an area of 224,298.98 $\mathrm{km}^{2}$ between the latitudes $5^{\circ} 16^{\prime} \mathrm{N}$ and $1^{\circ} 25^{\prime} \mathrm{S}$; and the longitudes $58^{\circ} 55^{\prime} \mathrm{W}$ and $64^{\circ} 48^{\prime} \mathrm{W}$ (IBGE 2010), corresponding to $2.6 \%$ of the Brazilian territory or $5.3 \%$ of the Amazonian Biome (Funcate 2006).

Chrysopidae specimens were captured with McPhail traps in the state of Roraima during intensive surveys of fruit flies (Diptera: Tephritidae). This work reports the captured species, the number of collected specimens and the respective municipalities where they were found.

\section{MATERIAL AND METHODS}

The chrysopids were captured with plastic McPhail traps containing $400 \mathrm{~mL}$ of food bait (hydrolyzed corn protein at 5\%, stabilized with borax - BioAnastrepha®), which is traditionally used in fruit fly surveys and monitoring programs.

The traps were set up on fruit trees (about $1.70 \mathrm{~m}$ above the ground) in the domestic orchards of small rural properties in four municipalities of the state of Roraima: Boa Vista, Bonfim, Pacaraima, and Amajari (Figure 1).

The predominant vegetation at the collection sites is the Cerrado biome, with the exception of Amajari, where the Amazon Forest biome prevails. The number of installed traps and their duration of exposure in each municipality were as follows: Boa Vista - 6 traps, October/2007 through December/2008; Bonfim - 2 traps, October/2007 through December/2008; Pacaraima - 2 traps, January through December/2008; and Amajari - 2 traps, April through June/2009.

The captured chrysopids were taken from the traps, placed in $70 \%$ ethanol, and sent to the Universidade Estadual Paulista (UNESP) in Jaboticabal, São Paulo, for identification. The abdomens of the insects were macerated in a $10 \%$ potassium hydroxide solution for one hour and colored in a solution of Chlorazol Black. The genitalia were subsequently externalized and the species were identified according to the morphological characteristics of these structures. Voucher specimens were deposited in the entomological collection of the Departamento de Fitossanidade at UNESP, Jaboticabal Campus. 


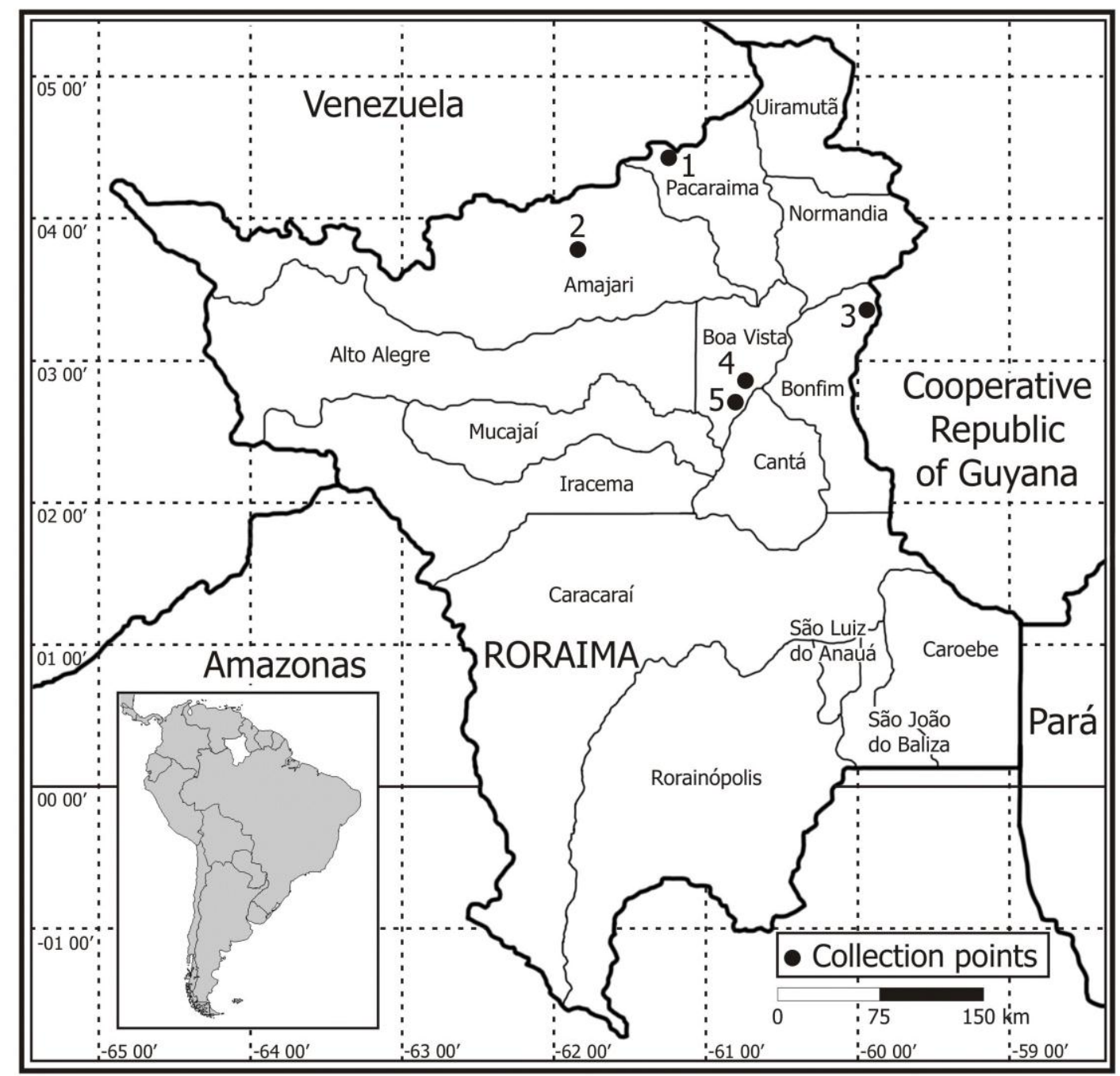

Figure 1. Map of the state of Roraima showing the locations of the McPhail* traps used for chrysopid collection in the four studied municipalities.

*Point 1 (Pacaraima, 2 traps; N 04²9'19.7", W 6107'52.0"; N 04²8'52.1", W

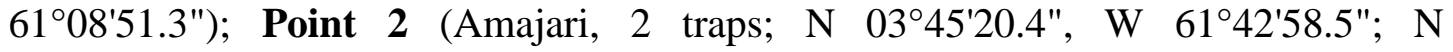
0346'47.9", W 6143'50.7"); Point 3 (Bonfim, 2 traps; N 0321'39.2", W 59॰50'00.5"; N 0322'47.0", W 5948'52.5"); Point 4 (Boa Vista, 4 traps; N 02 51'43.4", W 6040'06.2"; N 0253'56.3", W 60³9'34.4"; N 0253'51.6", W 60'39'35.2"; N 02 57'03.6", W 6042'21.3"); Point 5 (Boa Vista, 2 traps; N $02^{\circ} 45^{\prime} 24.1^{\prime \prime}, \mathrm{W} 60^{\circ} 42^{\prime} 54.0^{\prime \prime}$; $\left.\mathrm{N} \mathrm{02} 45^{\circ} 25.0^{\prime \prime}, \mathrm{W} 60^{\circ} 43^{\prime} 47.7^{\prime \prime}\right)$.

\section{RESULTS AND DISCUSSION}

We collected 459 specimens of Chrysopidae belonging to three genera: Leucochrysa, Ceraeochrysa, and Plesiochrysa (Table 1). Leucochrysa presented the highest species richness, namely nine identified species and one new species that still requires description. Ceraeochrysa presented the second highest species richness, namely seven identified species. We identified only one of the two collected species of Plesiochrysa. The other still requires description.

In the municipality of Boa Vista, Leucochrysa (Nodita) cruentata (Schneider) 
was the most abundant species $(54.2 \%$ of all collected individuals), followed by Ceraeochrysa valida (Banks) (29.3\%) (Table 1). The opposite occurred in Bonfim: the most abundant species was $C$. valida $(60.4 \%)$, followed by $L$. (N.) cruentata $(14.6 \%)$. The species with the broadest distribution was $L$. (N.) cruentata, which we collected in three of the four municipalities (Table 1).

The higher species richness and larger number of Chrysopidae specimens obtained in Boa Vista may have been due to the higher number and longer exposure of the traps installed in that municipality, as compared to the other three. Therefore we cannot affirm that Boa Vista presents the highest species richness among the sampled municipalities. New studies using equivalent numbers of traps and exposure times should be performed to provide consistent data of which municipality contains the highest species richness.

Among the Leucochrysa species collected in this work, L. (N.) cruentata, $L$. (N.) marquezi (Navás), L. (N.) camposi (Navás), L. (N.) heriocles (Banks), L. (N.) marginalis (Banks), L. (N.) squamisetosa Freitas \& Penny, and $L$. (N.) vittata Freitas \& Penny have already been reported in Brazil. The species $L$. (N.) cruentata has previously been collected in a mango orchard (Montes et al. 2007a) and in a coffee plantation (Agostini et al. 2007), both in the State of São Paulo. L. (N.) marquezi has been collected in a cucurbit plantation, also in São Paulo (Lavagnini et al. 2007). L. (N.) camposi has previously been collected in eucalyptus plantations in São Paulo (Montes et al. 2007b) and in citrus plantations in the State of Pará (Maia et al. 2010), and L. (N.) vittata has been collected in a mango orchard in São Paulo (Montes et al. 2007a).
All of the Leucochrysa species collected and identified in this work are firsttime reports for the state of Roraima. L. (N.) amazonica (Navás) and L. (N.) pavida (Hagen) are reported herein for the first time in Brazil. We also collected one new species of Leucochrysa, referred to in this work as Leucochrysa (Nodita) sp., which is still pending description.

Six of the Ceraeochrysa species collected in this work, namely $C$. acmon (Penny), C. caligata (Banks), C. scapularis (Navás), $C$. fairchildi (Banks), $\quad C$. acutipuppis (Adams \& Penny), and C. cincta (Schneider), have already been reported in Brazil. $C$. acmon and $C$. caligata have previously been collected in eucalyptus plantations in the state of São Paulo (Montes et al. 2007b) and in citrus plantations in the State of Pará (Maia et al. 2010). C. acutipuppis has been reported in Roraima by Adams \& Penny (1985), and C. fairchildi has previously been collected in Roraima on citrus and myrtle plants, by Marsaro Júnior et al. (2010). The species C. scapularis has already been reported in Roraima (Adams \& Penny 1985) and Pernambuco (Macedo \& Freitas 2008), and C. cincta has been observed in Pará (Maia et al. 2010), São Paulo (Agostini et al. 2007) and Paraná (Barbosa et al. 2009). This work comprises the first report of $C$. acmon, C. caligata and C. cincta in Roraima, and the first report of C. valida in Brazil.

Within the genus Plesiochrysa, we identified the species $P$. brasiliensis (Schneider). This species has previously been collected in a cucurbit plantation in São Paulo (Lavagnini et al. 2007), but this is the first report in the state of Roraima. One new species of Plesiochrysa, designated in this work as Plesiochrysa sp., was also collected and requires description. 
Table 1. Chrysopidae species captured with McPhail traps in four municipalities of the State of Roraima: Boa Vista (October/2007 through December/2008), Bonfim (October/2007 through December/2008), Pacaraima (January through December/2008), and Amajari (April through June/2009).

\begin{tabular}{|c|c|c|c|c|c|c|c|c|c|c|}
\hline \multirow[t]{3}{*}{ Species } & \multicolumn{8}{|c|}{ Municipalities in Roraima } & \multirow{2}{*}{\multicolumn{2}{|c|}{ Total }} \\
\hline & \multicolumn{2}{|c|}{ Boa Vista $^{1}$} & \multicolumn{2}{|c|}{ Bonfim $^{2}$} & \multicolumn{2}{|c|}{ Pacaraima $^{2}$} & \multicolumn{2}{|c|}{ Amajari $^{2}$} & & \\
\hline & Specimens & $\%$ & Specimens & $\%$ & Specimens & $\%$ & Specimens & $\%$ & Specimens & $\%$ \\
\hline Ceraeochrysa acmon* & 3 & 0.7 & 0 & 0.0 & 0 & 0.0 & 0 & 0 & 3 & 0.7 \\
\hline Ceraeochrysa acutipuppis & 0 & 0 & 1 & 2.1 & 0 & 0.0 & 0 & 0 & 1 & 0.2 \\
\hline Ceraeochrysa caligata* & 2 & 0.5 & 0 & 0.0 & 1 & 33.3 & 0 & 0 & 3 & 0.7 \\
\hline Ceraeochrysa cincta* & 0 & 0 & 1 & 2.1 & 0 & 0.0 & 0 & 0 & 1 & 0.2 \\
\hline Ceraeochrysa fairchildi & 5 & 1.2 & 5 & 10.4 & 0 & 0.0 & 0 & 0 & 10 & 2.2 \\
\hline Ceraeochrysa scapularis & 10 & 2.5 & 0 & 0.0 & 0 & 0.0 & 0 & 0 & 10 & 2.2 \\
\hline Ceraeochrysa valida** & 119 & 29.3 & 29 & 60.4 & 0 & 0.0 & 0 & 0 & 148 & 32.2 \\
\hline Leucochrysa (Nodita) amazonica** & 0 & 0 & 1 & 2.1 & 0 & 0.0 & 0 & 0 & 1 & 0.2 \\
\hline Leucochrysa (Nodita) camposi* & 7 & 1.7 & 0 & 0.0 & 0 & 0.0 & 0 & 0 & 7 & 1.5 \\
\hline Leucochrysa (Nodita) cruentata* & 220 & 54.2 & 7 & 14.6 & 2 & 66.7 & 0 & 0 & 229 & 49.9 \\
\hline Leucochrysa (Nodita) heriocles* & 0 & 0 & 0 & 0.0 & 0 & 0.0 & 1 & 50 & 1 & 0.2 \\
\hline Leucochrysa (Nodita) marginalis* & 8 & 2 & 2 & 4.2 & 0 & 0.0 & 0 & 0 & 10 & 2.2 \\
\hline Leucochrysa (Nodita) marquezi* & 21 & 5.2 & 0 & 0.0 & 0 & 0.0 & 0 & 0 & 21 & 4.6 \\
\hline Leucochrysa (Nodita) squamisetosa* & 1 & 0.2 & 0 & 0.0 & 0 & 0.0 & 0 & 0 & 1 & 0.2 \\
\hline Leucochrysa (Nodita) vittata* & 1 & 0.2 & 0 & 0.0 & 0 & 0.0 & 0 & 0 & 1 & 0.2 \\
\hline Leucochrysa (Nodita) sp. & 3 & 0.7 & 0 & 0.0 & 0 & 0.0 & 0 & 0 & 3 & 0.7 \\
\hline Plesiochrysa brasiliensis* & 6 & 1.5 & 0 & 0.0 & 0 & 0.0 & 0 & 0 & 6 & 1.3 \\
\hline Plesiochrysa sp. & 0 & 0 & 2 & 4.2 & 0 & 0.0 & 0 & 0 & 2 & 0.4 \\
\hline Total & 406 & 100 & 48 & 100 & 3 & 100 & 2 & 100 & 459 & 100 \\
\hline
\end{tabular}

six traps, ${ }^{2}$ two traps

* first report in Roraima

**first report in Brazil 
The obtained results indicate that Roraima presents a high richness of Chrysopidae species, which were partially surveyed in the four studied municipalities. Hence, for in-depth knowledge on species diversity in this important neuropteran family, we suggest that new surveys be completed in the state's many different ecosystems, covering a larger number of municipalities. Moreover, with regard to the collected species, we suggest that studies should be performed to assess their potential as agents for biological control of pests under the edaphoclimatic conditions found in Roraima.

\section{REFERENCES}

ADAMS, P. A.; PENNY, N. D. 1985. Neuroptera of the Amazon Basin. Acta Amazonica, v.15, n.3-4, p.413-479.

AGOSTINI, L. T.; MONTES, S. M. N.; FREITAS, S.; PONTES, R. M. O.; SATO, M. E.; RAGA, A. 2007. Ocorrência e flutuação populacional de crisopídeos em café na região oeste do estado de São Paulo. In Simpósio de Controle Biológico, 10., Sociedade Entomológica do Brasil, Brasília, 1 CD ROM.

BARBOSA, A. P.; ALBUQUERQUE, F. A.; FREITAS, S. 2009. Ocorrência e identificação taxonômica de crisopídeos (Neuroptera: Chrysopidae) na região de Maringá, PR. In Simpósio de Controle Biológico, 11., Sociedade Entomológica do Brasil, Bento Gonçalves, 1 CD ROM.

BROOKS, S. J.; BARNARD, P. C. 1990. The green lacewings of the world: a generic review (Neuroptera: Chrysopidae). Bulletin British Museum of Natural History, v.59, p.117-286.
CARDOSO, J. T.; LÁZZARI, S. M. N.; FREITAS, S.; IEDE, E. T. 2003. Ocorrência e flutuação populacional de Chrysopidae (Neuroptera) em áreas de plantio de Pinus taeda (L.) (Pinaceae) no sul do Paraná. Revista Brasileira de Entomologia, v.47, n.3, p.473-475.

COSTA, R. I. F.; SOUZA, B.; FREITAS, S. 2010. Dinâmica espaço-temporal de taxocenoses de crisopídeos (Neuroptera: Chrysopidae) em ecossistemas naturais. Neotropical Entomology, v.39, n.4, p.470-475.

FUNCATE. 2006. Uso e cobertura da terra na floresta amazônica: PROBIO subproject 106/2004. São José dos Campos, 154p. Report (Projeto de Conservação e Utilização Sustentável da Diversidade Biológica Brasileira Secretaria de Biodiversidade e Florestas do Ministério de Meio Ambiente, Conselho Nacional de Desenvolvimento Científico e Tecnológico, Fundo para o Meio Ambiente Global e Banco Mundial). Available at: < http://mapas.mma.gov.br/geodados/brasi 1/vegetacao/vegetacao2002/amazonia/do cumentos/relatorio_final.pdf $>$. Accessed on: 31 Oct. 2009.

FREITAS, S. 2005. New species of Brazilian Green Lacewings genus Leucochrysa McLachlan, 1868 (Neuroptera Chrysopidae). Ann. Mus. Civ. St. Nat. Ferrara, v.8, p.49-54.

FREITAS, S. 2007. Ocorrência de Ungla Navás (Neuroptera, Chrysopidae) no Brasil e descrição de nova espécie. Revista Brasileira de Entomologia, v.51, n.4, p.413-415.

GALLI, J. C.; SENÔ, K. C. A.; CIVIDANES, F. J. 2004. Dinâmica 
populacional de crisopídeos (Neuroptera: Chrysopidae) associados a pomares de goiaba Psidium guajava L. com dois sistemas de pulverização de fenthion. Bol. San. Veg. Plagas, v.30, p.197-202.

IBGE. 2010. Roraima - Synthesis. Available at:<http://www.ibge.gov.br/estadosat/pe rfil.php?sigla=rr>. Accessed on: 21 jun. 2010.

LAVAGNINI, T. C.; MONTES, S. M. N. M.; FREITAS, S.; PONTES, R. M. O. 2007. Levantamento populacional de crisopídeos em cucurbitáceas para exportação. In Simpósio de Controle Biológico, 10., Sociedade Entomológica do Brasil, Brasília, 1 CD ROM.

MAIA, W. J. M. S.; FREITAS, S.; ISHIDA, E. T.; SANTOS, R. S. E.; RODRIGUES, Y. T.; MAIA, T. J. A. F.; SANCHES, D. C.; SILVA, A. C. 2010. Diversidade de Neuroptera em Sto. Antônio do Tauá e Capitão Poço, PA. In Congresso Brasileiro de Entomologia, 23., Sociedade Entomológica do Brasil, Natal, 1 CD ROM.

MACEDO, L. P. M.; FREITAS, S. 2008. Ocorrência de crisopídeos (Neuroptera: Chrysopidae) na região de Floresta, Sertão de Itaparica, Estado de Pernambuco. In Congresso Brasileiro de Entomologia, 22., Sociedade Entomológica do Brasil, Uberlândia, 1 CD ROM.

MACEDO, L. P. M.; FREITAS, S. 2011. Ocorrência de mais duas espécies de Chrysoperla (Neuroptera: Chrysopidae) no Brasil. In Simpósio de Controle Biológico, 12., Sociedade Entomológica do Brasil, São Paulo, 1 CD ROM.
MARSARO JÚNIOR, A. L.; GUIDOLIN, A. S.; CÔNSOLI, F. L.; FREITAS, S.; ASTÚA, J. F. 2010. Primeiro registro de Diaphorina citri Kuwayama (Hemiptera: Psyllidae) e de seu predador Ceraeochrysa fairchildi Banks (Neuroptera: Chrysopidae) no estado de Roraima. In Congresso Brasileiro de Entomologia, 23., Sociedade Entomológica do Brasil, Natal, 1CD ROM.

MONTES, S. M. N. M.; FREITAS, S.; PONTES, R. M. O. 2007a. Levantamento de crisopídeos em pomar de manga (Mangifera indica L.) no oeste do estado de São Paulo. In Simpósio de Controle Biológico, 10., Sociedade Entomológica do Brasil, Brasília, 1CD ROM.

MONTES, S. M. N. M.; FREITAS, S.; RAGA, A.; PONTES, R. M. O. 2007b. Levantamento de Chrysopidae (Neuroptera) em variedades de eucalipto (Eucaliptus sp.) no oeste do estado de São Paulo. Biológico, v.69, n.2, p.188.

SILVA, M.; BEZERRA, C. E. S.; SOUZA, B.; COSTA, R. I. F. 2011. Levantamento de crisopídeos (Neuroptera: Chrysopidae) na mata do Baú, Barroso, MG. In Congresso de Ecologia do Brasil, 10., Sociedade de Ecologia do Brasil, São Lourenço, 3p. Available at: <http://www.sebecologia.org.br/xceb/resumos/1847.pdf> , acesso em 05/10/2011.

SOUZA, B.; COSTA, R. I. F.; LOUZADA, J. N. C. 2004. Diversidade de Chrysopidae (Insecta: Neuroptera) em fragmentos florestais e agroecossistemas. In Congresso Brasileiro de Entomologia, 20., Sociedade Entomológica do Brasil, Gramado, 1CD ROM. 